\title{
Theoretical nursing conceptions in hospitalized child care: scoping review
}

\author{
Concepções teóricas de enfermagem nos cuidados à criança hospitalizada: scoping review \\ Concepciones teóricas de enfermería en los cuidados al niño hospitalizado: scoping review
}

Escola Superior de Saúde Egas Moniz. Setúbal, Portugal.

"Universidade Católica Portuguesa. Instituto de Ciências da Saúde. Lisboa, Portugal.

How to cite this article:

Loureiro FM, Antunes AVRA, Charepe ZB. Theoretical nursing conceptions in hospitalized child care: scoping review.

Rev Bras Enferm. 2021;74(3):e20200265.

https://doi.org/10.1590/0034-7167-2020-0265

Corresponding author:

Fernanda Loureiro

E-mail: floureiro@egasmoniz.edu.pt

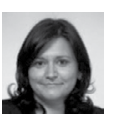

EDITOR IN CHIEF: Dulce Barbosa
ASSOCIATE EDITOR: Priscilla Broca

\section{ABSTRACT}

Objective: Identify the theoretical concepts that have been used in the context of nursing care for hospitalized children. Methods: Scoping review was carried out according to the PRISMA-SCR methodology. The research limitations included: primary studies dealing with the use of theoretical concepts of nursing in the provision of care to hospitalized children, access in full text, in Portuguese or English and published between 2000 and 2019. Research was carried out on grassroots platforms (EBSCOhost, PubMed, SciELO and Web of Science), gray literature and in the bibliography of selected articles. Results: 21 studies were found and 10 theoretical conceptions of nursing were identified, with family-centered care being the most used. Final considerations: The variability of the identified theoretical conceptions is emphasized, with no evidence to support the use of one in detriment of the other. A more integrative theoretical conception, which adds care centered both on the family and the child, emerges as a research trend.

Descritores: Nursing; Child; Hospitalization; Review; Nursing Theory.

\section{RESUMO}

Objetivo: Identificar as concepções teóricas que têm sido utilizadas no contexto da assistência de enfermagem à criança hospitalizada. Métodos: Realizou-se scoping review segundo a metodologia PRISMA-ScR. Os limitadores de pesquisa incluíram: estudos primários que versassem sobre utilização de concepções teóricas de enfermagem na prestação de cuidados à criança hospitalizada, acesso em texto integral, no idioma português ou inglês e publicados entre 2000 e 2019. Realizou-se pesquisa em plataformas de bases de dados (EBSCOhost, PubMed, SciELO e Web of Science), literatura cinzenta e na bibliografia dos artigos selecionados. Resultados: Foram encontrados 21 estudos e identificadas 10 concepções teóricas de enfermagem, sendo o cuidado centrado na família a mais utilizada. Considerações finais: Salienta-se a variabilidade das concepções teóricas identificadas, sem evidência que suporte a utilização de uma em detrimento de outra. Uma concepção teórica mais integradora, que agregue o cuidado centrado quer na família quer na criança, emerge enquanto tendência de investigação.

Descritores: Enfermagem; Criança; Hospitalização; Revisão; Teoria de Enfermagem.

\section{RESUMEN}

Objetivo: Identificar concepciones teóricas que han sido utilizadas en contexto de asistencia de enfermería al niño hospitalizado. Métodos: Realizó scoping review segundo metodología PRISMA-SCR. Delimitadores de investigación incluyeron: estudios primarios que versaron sobre utilización de concepciones teóricas de enfermería en prestación de cuidados al niño hospitalizado, acceso en texto integral, en idioma portugués o inglés y publicados entre 2000 y 2019. Realizó investigación en plataformas de bases de datos (EBSCOhost, PubMed, SciELO y Web of Science), literatura gris y en bibliografía de artículos seleccionados. Resultados: Encontrados 21 estudios e identificadas 10 concepciones teóricas de enfermería, siendo el cuidado centrado en la familia la más utilizada. Consideraciones finales: Destaca la variabilidad de las concepciones teóricas identificadas, sin evidencia que suporte la utilización de una en detrimento de otra. Una concepción teórica más integradora, que agregue el cuidado centrado tanto en la familia como en el niño, emerge mientras tendencia de investigación. Descriptores: Enfermería; Niño; Hospitalización; Revisión; Teoría de Enfermería. 


\section{INTRODUCTION}

The progression of nursing as a discipline is the result of the contributions of research, practice and theory as cornerstones, in a reciprocal and cyclical relationship ${ }^{(1)}$. Research guides practice and builds knowledge by developing the theory; clinical practice raises questions of investigation and knowledge for the theory; and this guide investigates and improves practice ${ }^{(2)}$. Additionally, it is necessary to analyze the theory in order to clarify the nursing intervention domain, guide nursing science and practice. It is also essential to direct and communicate the unique and essential contribution of nursing in the quality of science to health research and health care ${ }^{(3)}$.

Theoretical conceptions guide care and offer an organized and sustained knowledge approach ${ }^{(4-5)}$. The levels of knowledge structure in nursing are presented by Alligood \& Tomey ${ }^{(6)}$ and organized into: metaparadigm; philosophy; conceptual model; great theory; theory; and medium-range theory. In this sense, the theoretical conceptions of nursing encompass the view of the discipline and practice based on a key concept and the relationships between two or more nursing concepts developed for their transference in care practice ${ }^{(7-8)}$. By using theory in daily care practice, nurses find a sense of purpose and a direction that is consistent with basic nursing values ${ }^{(1)}$. Additionally, in nursing, as in any other discipline, science is the result of the relationship between the research process and the knowledge product ${ }^{(2)}$. The primary purpose of theory in the nursing profession is to improve practice by having a positive influence on people's health and quality of life, which is why the relationship between theory and practice is reciprocal ${ }^{(1-2)}$. In this sense, when looking at nursing care in a given context, it is crucial to identify how they are supported from the theoretical point of view ${ }^{(9)}$.

Within the scope of nursing care provided to hospitalized children, the development of theory in the disciplinary area of nursing is still very recent. In fact, until around 1950, hospitals around the world were poorly prepared and adapted to the paediatric population. With the realization of the adverse effects of hospitalization and the impact of separation from the family, the policy of joint accommodation and change in the paradigm of health care began ${ }^{(10)}$. The conceptualization of care reflects this nursing practice that integrates the family as an active member of the health team. In this sense, it is important to understand the way the nursing team conceives care for children and families, in the context of hospitalization, as it influences the mode of care delivery ${ }^{(11)}$.

Thus, it was considered pertinent to map, based on the scientific literature associated with the nursing discipline, the available evidence about the use of theoretical concepts of nursing used in the care of hospitalized children. A scoping review was carried out according to the Preferred Reporting Items for Systematic Reviews and Meta-Analyses Extension for Scoping Reviews methodology $(\mathrm{PRISMA}-\mathrm{SCR})^{(12)}$. It is a type of review that allows mapping the relevant literature in a field of useful interest, for broad themes and diversified methodologies, in a less restrictive inclusion format and, therefore, with a greater range of evidence ${ }^{(13)}$.

\section{OBJECTIVE}

Identify which theoretical concepts have been used in the context of nursing care for hospitalized children.
It should be noted that the term "theoretical conceptions" was chosen as the most comprehensive designation and that, in this manuscript, other terms were included (eg, models). The following research question was defined: What are the theoretical concepts used in the context of nursing care for hospitalized children. It should be noted that, in the research question, the acronym PCC was used (Population: child and parents; Concept: theoretical concepts; Context: hospitalization).

\section{METHODS}

A Literature review was carried out according to the steps defined by PRISMA-ScR ${ }^{(12)}$.

\section{Protocol and registration}

The research protocol was written, reviewed and verified by the authors. Prospectively registered with the Open Science Framework, on April 8, 2020 (http://osf.io/zhjvm/).

\section{Eligibility criteria}

The following inclusion criteria were defined: studies dealing with the use of theoretical concepts of nursing in the provision of care to children and families in hospital; context of study in hospitalization services; primary qualitative, quantitative studies with triangulation of methods, including literature reviews in order to maximize the coverage of available evidence; articles available in full text, in Portuguese or English; publication date between 01-01-2001 and 30-09-2019. The option for this time limit aimed to obtain data that would allow the characterization of the theoretical concepts in use in the 21st century.

As exclusion criteria, the following were rejected: articles that addressed very specific contexts (eg, intensive care units and neonatology units), given the particularities of nursing care in these units; articles that did not clearly identify the theoretical concept of nursing; opinion articles; editorials; advertising; and letters to the editor.

\section{Information sources}

In the research, the strategy in three stages was used as recommended ${ }^{(14)}$. Initially, a search was made in two databases (MEDLINE [with full text] and CINAHL [with full text]), followed by an analysis of the words contained in the title and summary of the selected articles, as well as the key terms. The objective was to improve the keywords to include in the research equation, adapting them to the Health Sciences Descriptors (DeCS).

In the second stage, after identifying the descriptors to be used, the research equation was created and the search was carried out, using the electronic platform EBSCOhost, in the following databases: Cumulative Index to Nursing and Allied Health Literature (CINAHL) [complete], MEDLINE [complete], Nursing \& Allied Health Collection [comprehensive]; Cochrane Central Register of Controlled Trials, Cochrane Database of Systematic Reviews, Cochrane Methodology Register; Library, Information Science \& Technology Abstracts (LIST) and MedicLatina. Additionally, 
research was done on the PubMed platforms; at SciELO; and the Web of Science.

Grey literature research was used, namely: Open Grey; Portuguese Open Access Scientific Repository; Veritati - Institutional repository of the Portuguese Catholic University; MedNar Search; and WorldWideScience.org - The Global Science Gateway.

The bibliographic reference list of the selected articles was systematically consulted as a way of identifying relevant works for this review.

\section{Search}

The applied research equation, using Boolean descriptors and operators, was as follows: ((Model OR theory) AND (child * OR pediat ${ }^{*}$ ) AND (hosp *) AND (nurs *)). The database search took place in October 2019 and was carried out by FL and reviewed by ZC. The sample initially oTTained in the different databases was limited according to the inclusion criteria and fields available in the databases, as shown in Chart 1.

Chart 1 - Synthesis of the platforms and limiters used, as a research strategy

\begin{tabular}{|c|c|}
\hline Platform & Limiters \\
\hline EBSCOhost & $\begin{array}{l}\text { Portuguese or English language; } \\
\text { Published between 01-01-2000 and } \\
\text { 30-09-2019; } \\
\text { Full text available; }\end{array}$ \\
\hline SciELO & $\begin{array}{l}\text { Portuguese or English language; } \\
\text { Published between } 2000 \text { and 2019; }\end{array}$ \\
\hline PubMed & $\begin{array}{l}\text { Published between } 01-01-2000 \text { and } \\
30-09-2019 ; \\
\text { Full text available; }\end{array}$ \\
\hline Web of Science & $\begin{array}{l}\text { Published between } 2000 \text { and 2019; } \\
\text { Full text available; }\end{array}$ \\
\hline The grey literature report & Site unavailable; \\
\hline Open grey & $\begin{array}{l}\text { Published between } 2000 \text { and 2019; } \\
\text { Full text available; }\end{array}$ \\
\hline $\begin{array}{l}\text { Portugal Open Access Scientific } \\
\text { Repository }\end{array}$ & $\begin{array}{l}\text { Portuguese or English language; } \\
\text { Full text available; }\end{array}$ \\
\hline $\begin{array}{l}\text { Veritati - Institutional Repository } \\
\text { of the Portuguese Catholic } \\
\text { University }\end{array}$ & Full text available; \\
\hline MedNar search & $\begin{array}{l}\text { Published between } 2000 \text { and 2019; } \\
\text { Full text available; }\end{array}$ \\
\hline Worldwidescience.org & $\begin{array}{l}\text { Portuguese or English language; } \\
\text { Published between } 2000 \text { and 2019; } \\
\text { Full text available; }\end{array}$ \\
\hline
\end{tabular}

\section{Selection of sources of evidence}

The studies were selected by reading the title; and, when it was not clear whether the article answered the research question, the abstracts were read. Repeated articles were removed and the inclusion and exclusion criteria were applied. The process was carried out independently by two reviewers, and consensus was reached for the final list of articles.

\section{Data selection and analysis process}

After constituting the corpus of analysis, data extraction was carried out using information systematization tables, taking into account the research question and with a view to comparing scientific evidence. Data extraction was carried out by two authors and reviewed by all authors.

\section{Listing the data}

The data were listed in a table format, with the aim of seeking information, namely the following elements ${ }^{(14)}$ : Authors; Year of publication; Parents; Goals; Population and sample; Methodology; Theoretical conception; Results; Main conclusions.

\section{Summary of results}

The systematization table gathered all the relative information extracted individually by two authors and approved by consensus by all authors. Data were collected in order to contextualize the use of nursing theories and to relate the objective of the study on screen to the objective of this review.

\section{RESULTS}

\section{Selection of sources of evidence}

The research strategy allowed the identification of 21 articles, which constitute the corpus of analysis of this review, as shown schematically in Figure 1.

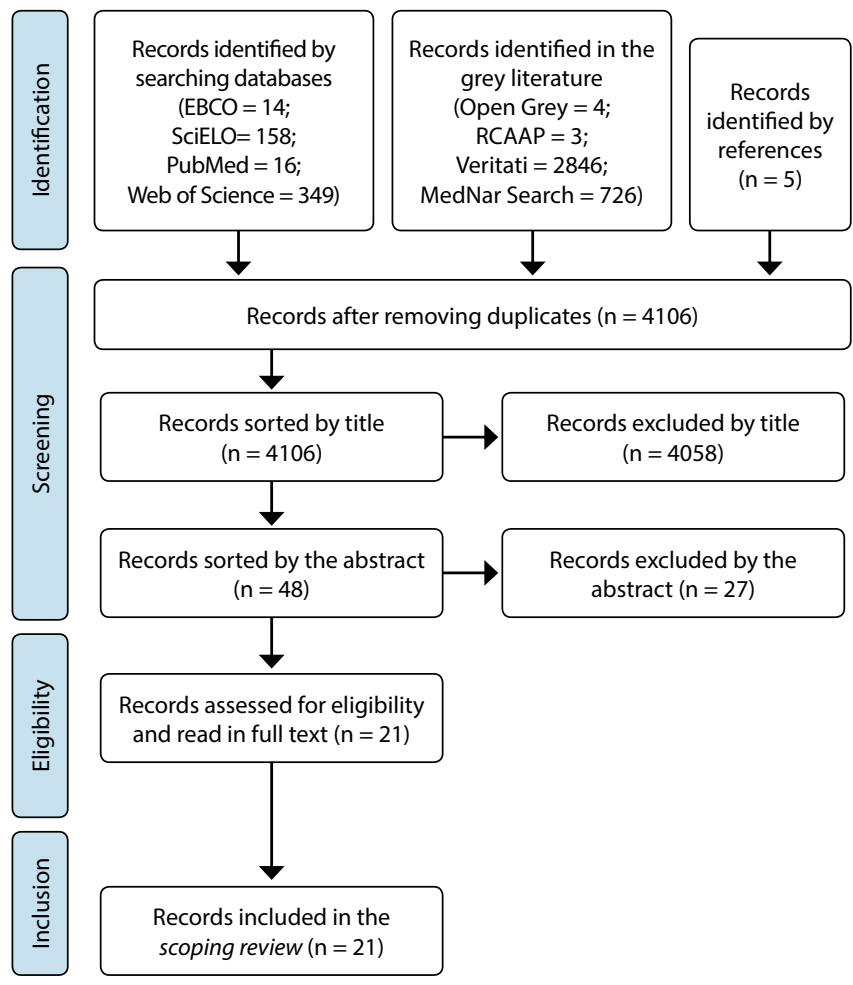

Figure 1 - PRISMA flowchart of the study selection process 


\section{Characteristics of evidence sources}

This review allowed the identification of a total of ten theoretical concepts applicable to nursing care in the context of child hospitalization and which are summarized in Chart 2. We emphasize that the different theoretical concepts are identified next to the name, with reference to the respective author assuming the its original designation.

Chart 2 - Synthesis of theoretical concepts found in the scoping review

\begin{tabular}{|l|l|}
\hline Theoretical conception & Author, year; \\
\hline Family-centered care & $\begin{array}{l}\text { Boztepe \& Yıldız, 2017; } \\
\text { Coyne, 2015; } \\
\text { Khajeh et al., 2017; } \\
\text { Matziou et al., 2018; } \\
\text { Mendes \& Martins, 2012; } \\
\text { Miranda, Oliveira, Toia, \& Stucchi, 2015; } \\
\text { Shields, Pratt, Davis, \& Hunter, 2007; } \\
\text { Watts et al., 2014; }\end{array}$ \\
\hline $\begin{array}{l}\text { Theory of basic human } \\
\text { needs }\end{array}$ & $\begin{array}{l}\text { Dantas, Silva, \& Nóbrega, 2018; } \\
\text { Marques, Silva, \& Nóbrega, 2016; } \\
\text { Santos, 2016; }\end{array}$ \\
\hline Care partnership model(16); & $\begin{array}{l}\text { Alves, 2015; } \\
\text { Sousa, 2012; }\end{array}$ \\
\hline Theory of human care ${ }^{(17) ;}$ & $\begin{array}{l}\text { Santos et al., 2014; } \\
\text { Santos, Silva, Misko, Poles, \& Bousso, 2013; }\end{array}$ \\
\hline $\begin{array}{l}\text { Child transitional } \\
\text { communication model }{ }^{(18) ;}\end{array}$ & Lambert, Glacken, \& McCarron, 2011; \\
\hline $\begin{array}{l}\text { Nursing care model caring } \\
\text { playing }{ }^{(19) ;}\end{array}$ & Caleffi et al, 2016; \\
\hline Quality-care model (20); $^{(2)}$ & Edmundson, 2012. \\
\hline Synergy model ${ }^{(21) ;}$ & Mullen \& Asher, 2007; \\
\hline Comfort theory ${ }^{(22) ;}$ & Kolcaba \& DiMarco, 2015; \\
\hline Neuman systems model ${ }^{(23) ;}$ & Ferreira et al., 2019; \\
\hline
\end{tabular}

\section{Individual results from evidence sources}

The results extracted from each study are summarized in Chart 3.

\section{Summary of results}

Of the articles that make up the corpus of analysis, the majority, more specifically 18 of the 21 articles, were published in the last ten years. With regard to the country of origin, there is variability, in particular articles from the following countries: Australia (1), Brazil (9), United States of America (3), Greece (1), England (1), Iran (1), Ireland (2), Portugal (3) and Turkey (1). As for the methodology, only one of the articles is of a quantitative nature ${ }^{(40)}$; also only one is of a theoretical nature ${ }^{(34)}$; and three are literature reviews ${ }^{(30,33,41)}$. In 12 of the articles found, interviews are used, as a method of data collection, in isolation ${ }^{(10,28,35,39)}$ or in conjunction with other forms, such as observation ${ }^{(18-19,29,32,38)}$ or focus group ${ }^{(36)}$. Two of the articles report the use of project work as a methodology ${ }^{(25,31)}$. In the 20 qualitative articles, the sample size varies between $7^{(19)}$ and $54^{(10)}$. Regarding the subjects, one of the studies has a sample composed of parents of hospitalized children ${ }^{(37)}$; one of them presents as sample parents and nurses ${ }^{(38)}$; two others have samples composed exclusively of children ${ }^{(18-19)}$; and two works use the perspectives of children, parents and nurses ${ }^{(10,32)}$. Most studies, specifically 11 of the 21 studies, have nurses as subjects ${ }^{(24-29,31,35-36,39-40)}$.

\section{DISCUSSION}

\section{Summary of the evidence}

The review made it possible to find several theoretical concepts used in the context of nursing care for hospitalized children. The variability of designations is evident, without unanimity in the nomenclature used. Chinn \& $\operatorname{Kramer}^{(1)}$ point out that, in its origin, the initial theoretical works of authors such as Callista Roy, Betty Neuman or Imogene King have sparked debate around the term to be used:"models", "theories" or "philosophies". They emphasize that it remains a topic still under debate, with varied terminology found in contemporary literature. Although there is a generalized understanding regarding the nursing metaparadigm, described by four concepts (person, environment, health and nursing), the same thing does not occur in other levels of knowledge structure(6). For example, family-centered care (FCCs) emerges predominantly in the quality of a philosophy, despite being commonly referred to as a paradigm, a theory or a concept ${ }^{(32)}$.

Chart 3 - Chart of systematization of studies included in the scoping review

\begin{tabular}{|c|c|c|c|c|c|}
\hline Title & $\begin{array}{c}\text { Year } \\
\text { Country }\end{array}$ & Outline & $\begin{array}{l}\text { Theoretical } \\
\text { Conception } \\
\text { Identified }\end{array}$ & Results & Main conclusions \\
\hline $\begin{array}{l}\text { Contribution } \\
\text { of structured } \\
\text { therapeutic play } \\
\text { in a nursing } \\
\text { care model for } \\
\text { hospitalised } \\
\text { children }^{(19)}\end{array}$ & $\begin{array}{l}2018 \\
\text { Brazil }\end{array}$ & $\begin{array}{l}\text { Objective: to analyze how TP } \\
\text { structured in a Nursing Care Model } \\
\text { contributes to the care of hospitalized } \\
\text { children; } \\
\text { Population and sample: Hospitalized } \\
\text { children; sample: } 7 \text { children (5-8 years); } \\
\text { Methodology: convergent care } \\
\text { research. } \\
\text { Open interview and participant } \\
\text { observation; }\end{array}$ & $\begin{array}{l}\text { Nursing care } \\
\text { model caring } \\
\text { playing; }\end{array}$ & $\begin{array}{l}\text { Three categories were } \\
\text { identified: meanings } \\
\text { attributed by the child } \\
\text { to hospitalization and its } \\
\text { influence on nursing care; } \\
\text { perception of therapeutic } \\
\text { procedures through TT; } \\
\text { importance of family } \\
\text { insertion in care; }\end{array}$ & $\begin{array}{l}\text { TT contributes to: the } \\
\text { reduction of the negative } \\
\text { effects of hospitalization; } \\
\text { clarify doubts and curiosities. } \\
\text { The model contributes to } \\
\text { comprehensive care directed } \\
\text { to the child's needs; }\end{array}$ \\
\hline
\end{tabular}


Chart 3

\begin{tabular}{|c|c|c|c|c|c|}
\hline Title & $\begin{array}{c}\text { Year } \\
\text { Country }\end{array}$ & Outline & $\begin{array}{l}\text { Theoretical } \\
\text { Conception } \\
\text { Identified }\end{array}$ & Results & Main conclusions \\
\hline $\begin{array}{l}\text { The practice of } \\
\text { nurses caring } \\
\text { for families } \\
\text { of pediatric } \\
\text { inpatients in light } \\
\text { of Jean Watson }\end{array}$ & $\begin{array}{l}2014 \\
\text { Brazil }\end{array}$ & $\begin{array}{l}\text { Objective: to know the facilities and } \\
\text { difficulties of nurses in the practice of } \\
\text { caring for the families of hospitalized } \\
\text { children; } \\
\text { Population and sample: nurses from } \\
\text { paediatric services; } 12 \text { nurses; } \\
\text { Methodology: qualitative; semi- } \\
\text { structured interviews, submitted to } \\
\text { inductive thematic analysis; }\end{array}$ & $\begin{array}{l}\text { Theory of } \\
\text { human care, by } \\
\text { Jean Watson; }\end{array}$ & $\begin{array}{l}\text { Three themes were } \\
\text { identified: recognizing } \\
\text { a reference for care; } \\
\text { considering the institutional } \\
\text { context; and challenges in } \\
\text { the relationship with the } \\
\text { family; }\end{array}$ & $\begin{array}{l}\text { The theory favored } \\
\text { reflections on the self, on } \\
\text { institutions and on the } \\
\text { relationship with the child's } \\
\text { family; }\end{array}$ \\
\hline $\begin{array}{l}\text { Implementation } \\
\text { of a nursing } \\
\text { professional } \\
\text { practice model of } \\
\text { care in a pediatric } \\
\text { hospital }^{(25)}\end{array}$ & $\begin{array}{c}2007 \\
\text { United } \\
\text { States of } \\
\text { America }\end{array}$ & $\begin{array}{l}\text { Objective: to describe the } \\
\text { implementation of the synergy model } \\
\text { in a pediatric hospital; } \\
\text { Population and sample: nursing staff at } \\
\text { a pediatric hospital; } \\
\text { Methodology: project work; }\end{array}$ & Synergy Model; & $\begin{array}{l}\text { The team was divided } \\
\text { into two groups that } \\
\text { implemented the model } \\
\text { across the hospital; }\end{array}$ & $\begin{array}{l}\text { The use of a professional } \\
\text { nursing practice model } \\
\text { is important because } \\
\text { it facilitates describing, } \\
\text { unravelling, guiding and } \\
\text { evaluating nursing practice; }\end{array}$ \\
\hline $\begin{array}{l}\text { Validation of } \\
\text { nursing diagnoses, } \\
\text { interventions and } \\
\text { outcomes in a } \\
\text { pediatric clinic }{ }^{(26)}\end{array}$ & $\begin{array}{l}2018 \\
\text { Brazil }\end{array}$ & $\begin{array}{l}\text { Objective: to elaborate the operational } \\
\text { definitions of the diagnostics } \\
\text { nomenclature of diagnoses, results } \\
\text { and nursing interventions of the } \\
\text { pediatric clinic of a teaching hospital } \\
\text { and to perform the content and clinical } \\
\text { validation of the nomenclature; } \\
\text { Population and sample: nursing staff at } \\
\text { a pediatric clinic; } \\
\text { Methodology: methodological } \\
\text { research with documentary study and } \\
\text { clinical case studies; }\end{array}$ & $\begin{array}{l}\text { Theory of basic } \\
\text { human needs, } \\
\text { by Wanda } \\
\text { Horta; }\end{array}$ & $\begin{array}{l}\text { There was effectiveness in } \\
\text { using the nomenclature in } \\
\text { this context; }\end{array}$ & $\begin{array}{l}\text { There was effectiveness in } \\
\text { using the nomenclature in } \\
\text { this context; }\end{array}$ \\
\hline $\begin{array}{l}\text { Hospitalized } \\
\text { school children: } \\
\text { proposition of a } \\
\text { data collection } \\
\text { instrument in light } \\
\text { of Horta's theory }^{(27)}\end{array}$ & $\begin{array}{l}2016 \\
\text { Brazil }\end{array}$ & $\begin{array}{l}\text { Objective: to build a data collection } \\
\text { instrument for hospitalized students in } \\
\text { the light of the theory of basic human } \\
\text { needs; } \\
\text { Population and sample: nursing staff at } \\
\text { a hospital; } 8 \text { nurses; } \\
\text { Methodology: methodological } \\
\text { research with statistical analysis to } \\
\text { validate empirical indicators; }\end{array}$ & $\begin{array}{l}\text { Theory of basic } \\
\text { human needs, } \\
\text { by Wanda } \\
\text { Horta; }\end{array}$ & $\begin{array}{l}\text { The indicators were } \\
\text { identified based on the } \\
\text { analysis of instruments } \\
\text { validated for children, } \\
\text { considering the International } \\
\text { Minimum Nursing Data Set. } \\
288 \text { indicators were oTTained } \\
\text { that underwent revalidation } \\
\text { and subsequent formatting } \\
\text { of the instrument in the final } \\
\text { version; }\end{array}$ & $\begin{array}{l}\text { The instrument has both } \\
\text { contributed to the data } \\
\text { collection of hospitalized } \\
\text { students and guided the } \\
\text { phases of the nursing } \\
\text { process, considering the } \\
\text { specific needs of school-age } \\
\text { children; }\end{array}$ \\
\hline $\begin{array}{l}\text { Unveiling } \\
\text { humanized } \\
\text { care: nurses' } \\
\text { perceptions } \\
\text { in pediatric } \\
\text { oncology }^{(28)}\end{array}$ & $\begin{array}{l}2013 \\
\text { Brazil }\end{array}$ & $\begin{array}{l}\text { Objective: to know the elements } \\
\text { of humanized care present in the } \\
\text { meeting between nurses, family and } \\
\text { children with cancer; identify the } \\
\text { perception of these nurses regarding } \\
\text { the humanization of assistance and } \\
\text { verify in which situations the nurse } \\
\text { perceives that humanization is } \\
\text { anchored to care; } \\
\text { Population and sample: nursing staff at } \\
\text { a hospital; } 9 \text { nurses; } \\
\text { Methodology: exploratory-descriptive } \\
\text { study; semi structured interview; }\end{array}$ & $\begin{array}{l}\text { Theory of } \\
\text { human care, by } \\
\text { Jean Watson; }\end{array}$ & $\begin{array}{l}\text { The theoretical elements } \\
\text { emerged from the } \\
\text { descriptions of clinical } \\
\text { events or situations } \\
\text { presented by nurses; }\end{array}$ & $\begin{array}{l}\text { The data allowed reflections } \\
\text { on possibilities of building } \\
\text { the interpersonal humanistic } \\
\text { process in the care } \\
\text { environment in paediatric } \\
\text { oncology and advances } \\
\text { and limitations regarding } \\
\text { the applicability of this } \\
\text { framework in practice; }\end{array}$ \\
\hline $\begin{array}{l}\text { Partnership } \\
\text { in paediatric } \\
\text { nursing care: } \\
\text { from discourse to } \\
\text { nurses' action }^{(29)}\end{array}$ & $\begin{array}{c}2012 \\
\text { Portugal }\end{array}$ & $\begin{array}{l}\text { Objective: to know in paediatric } \\
\text { nurses how they perceive the process } \\
\text { of building the partnership in the } \\
\text { practice of caring for parents and to } \\
\text { identify in the context the actions } \\
\text { taken; } \\
\text { Population and sample: nursing staff } \\
\text { from a paediatric service; } 12 \text { nurses. } \\
\text { Methodology: qualitative study } \\
\text { supported by grounded theory, } \\
\text { supported by the theoretical } \\
\text { framework of symbolic interactionism; } \\
\text { interview and observation; }\end{array}$ & FCCs; & $\begin{array}{l}\text { Working in partnership } \\
\text { with parents is present } \\
\text { in the nurses'"'thinking". } \\
\text { However, the observations } \\
\text { made showed gaps in } \\
\text { the contemplation of } \\
\text { dimensions that are } \\
\text { fundamental to the } \\
\text { development of an effective } \\
\text { partnership with parents; }\end{array}$ & $\begin{array}{l}\text { Nurses contemplate the } \\
\text { partnership in thinking, but } \\
\text { not in acting; }\end{array}$ \\
\hline
\end{tabular}




\begin{tabular}{|c|c|c|c|c|c|}
\hline Title & $\begin{array}{c}\text { Year } \\
\text { Country }\end{array}$ & Outline & $\begin{array}{l}\text { Theoretical } \\
\text { Conception } \\
\text { Identified }\end{array}$ & Results & Main conclusions \\
\hline $\begin{array}{l}\text { The evolution of } \\
\text { models of nursing } \\
\text { care for children } \\
\text { hospitalized in } \\
\text { the last } 30 \text { years: } \\
\text { from the disease- } \\
\text { centered model } \\
\text { to the child and } \\
\text { family-centered } \\
\text { model }^{(30)}\end{array}$ & $\begin{array}{l}2015 \\
\text { Brazil }\end{array}$ & $\begin{array}{l}\text { Objective: to identify the evolution } \\
\text { of nursing models for children } \\
\text { hospitalized in the last } 30 \text { years in } \\
\text { Brazil; } \\
\text { Population and sample: not applicable; } \\
\text { Methodology: descriptive, } \\
\text { retrospective and comparative } \\
\text { research through bibliographic } \\
\text { research; }\end{array}$ & $\begin{array}{l}\text { Child centered } \\
\text { pathology } \\
\text { model; } \\
\text { Child-centered } \\
\text { model; } \\
\text { Child-centered } \\
\text { model and } \\
\text { family; }\end{array}$ & $\begin{array}{l}\text { Three nursing models were } \\
\text { identified in the care of } \\
\text { hospitalized children; the } \\
\text { family-centered care model } \\
\text { is recognized as the ideal in } \\
\text { the national context; }\end{array}$ & $\begin{array}{l}\text { In order to implement the } \\
\text { model, it is necessary to } \\
\text { adapt the services, policies } \\
\text { and teams; }\end{array}$ \\
\hline $\begin{array}{l}\text { The Quality Caring } \\
\text { Nursing Model: } \\
\text { A Journey to } \\
\text { Selection and } \\
\text { Implementation }{ }^{(31)}\end{array}$ & $\begin{array}{c}2012 \\
\text { United } \\
\text { States of } \\
\text { America }\end{array}$ & $\begin{array}{l}\text { Objective: to describe the selection } \\
\text { and implementation process of a } \\
\text { theoretical model of nursing in a } \\
\text { pediatric hospital; } \\
\text { Population and sample: hospital } \\
\text { nursing staff; } \\
\text { Methodology: project methodology; }\end{array}$ & $\begin{array}{l}\text { Quality-care } \\
\text { model@; }\end{array}$ & $\begin{array}{l}\text { After research and } \\
\text { reflection, the quality-care } \\
\text { model was selected; the } \\
\text { implementation of the } \\
\text { model implied the use of } \\
\text { focus groups, tutorials via } \\
\text { the internet and educational } \\
\text { tools; }\end{array}$ & $\begin{array}{l}\text { The existence of a theoretical } \\
\text { model that guides nursing } \\
\text { practice is essential; the } \\
\text { chosen model values } \\
\text { relationships within the } \\
\text { scope of care as the basis for } \\
\text { professional practice; }\end{array}$ \\
\hline $\begin{array}{l}\text { Family } \\
\text { centered care } \\
\text { of hospitalized } \\
\text { children: A hybrid } \\
\text { concept analysis } \\
\text { in Iran } \\
\text { (32) }\end{array}$ & $\begin{array}{l}2017 \\
\text { Iran }\end{array}$ & $\begin{array}{l}\text { Objective: to analyze the concept of } \\
\text { FCCs in hospitalized children in Iran; } \\
\text { Population and sample: children, } \\
\text { parents, nurses and paediatricians in a } \\
\text { total of } 27 \text { participants; } \\
\text { Methodology: literature review, } \\
\text { semi-structured interviews and non- } \\
\text { participatory observation; }\end{array}$ & FCCs; & $\begin{array}{l}\text { In the literature, four central } \\
\text { themes to the FCCs were } \\
\text { identified: participation } \\
\text { of the family and health } \\
\text { professionals; sharing } \\
\text { information with the family; } \\
\text { relationships between } \\
\text { family and professionals } \\
\text { based on respect and } \\
\text { dignity; individualized } \\
\text { family care. The interviews } \\
\text { and observations allowed } \\
\text { the identification of the } \\
\text { following themes: family } \\
\text { as a non-participating visit; } \\
\text { education in a single sense; } \\
\text { unsupported interactions; } \\
\text { unspecified care for the } \\
\text { family; }\end{array}$ & $\begin{array}{l}\text { FCCs are comprehensive } \\
\text { care, and their } \\
\text { implementation is } \\
\text { affected by human and } \\
\text { organizational factors. } \\
\text { Family and professional } \\
\text { participation is required, } \\
\text { effective interactions with } \\
\text { the family, shared education } \\
\text { and information and } \\
\text { individualized care with each } \\
\text { family; }\end{array}$ \\
\hline $\begin{array}{l}\text { Families and } \\
\text { health-care } \\
\text { professionals' } \\
\text { perspectives and } \\
\text { expectations of } \\
\text { family-centred } \\
\text { care: hidden } \\
\text { expectations and } \\
\text { unclear roles }^{(10)}\end{array}$ & $\begin{array}{c}2015 \\
\text { Ireland }\end{array}$ & $\begin{array}{l}\text { Objective: to investigate the } \\
\text { implementation of FCCs from the } \\
\text { perspective of family members and } \\
\text { nurses; } \\
\text { Population: children, parents and } \\
\text { nurses in paediatric services; sample: } \\
18 \text { children ( } 7-16 \text { years), } 18 \text { parents and } \\
18 \text { nurses; } \\
\text { Methodology: interviews analyzed } \\
\text { using grounded theory; }\end{array}$ & FCCs; & $\begin{array}{l}\text { Four themes were } \\
\text { identified: expectations; rely } \\
\text { on the help of parents; work } \\
\text { in different roles; barriers to } \\
\text { the implementation of FCCs; }\end{array}$ & $\begin{array}{l}\text { Families are available to } \\
\text { help with child-care, but } \\
\text { they need information, } \\
\text { support and clear guidance } \\
\text { from nurses. These must } \\
\text { be trained and have the } \\
\text { appropriate resources to } \\
\text { respond to the needs of the } \\
\text { family: }\end{array}$ \\
\hline $\begin{array}{l}\text { Family-centered } \\
\text { care for } \\
\text { hospitalized } \\
\text { children aged } \\
0 \text {-12 years: a } \\
\text { systematic review } \\
\text { of qualitative } \\
\text { studies }^{(33)}\end{array}$ & $\begin{array}{c}2014 \\
\text { Austrália }\end{array}$ & $\begin{array}{l}\text { Objective: to investigate the effects of } \\
\text { FCC models in hospitalized children } \\
\text { aged 0-12 years; } \\
\text { Population and sample: not applicable; } \\
\text { Methodology: systematic literature } \\
\text { review; }\end{array}$ & FCCs; & $\begin{array}{l}\text { There is still little evidence of } \\
\text { the use of family-centered } \\
\text { care and its relationship } \\
\text { with the results of nursing } \\
\text { care; }\end{array}$ & $\begin{array}{l}\text { The use of family-centered } \\
\text { care appears to have } \\
\text { positive effects on increasing } \\
\text { parental satisfaction; }\end{array}$ \\
\hline $\begin{array}{l}\text { Comfort Theory } \\
\text { and its application } \\
\text { to pediatric } \\
\text { nursing }^{(34)}\end{array}$ & $\begin{array}{c}2015 \\
\text { United } \\
\text { States of } \\
\text { America }\end{array}$ & $\begin{array}{l}\text { Objective: to present the theory of } \\
\text { comfort and its application to the } \\
\text { practice of pediatric care; } \\
\text { Population and sample: not applicable; } \\
\text { Methodology: theoretical article; }\end{array}$ & $\begin{array}{l}\text { Comfort } \\
\text { Theory; }\end{array}$ & $\begin{array}{l}\text { The comfort theory was } \\
\text { presented; demonstrated } \\
\text { its application in a practical } \\
\text { case; described the } \\
\text { premises about comfort; } \\
\text { exposed how care focused } \\
\text { on comfort can be } \\
\text { organized; described how } \\
\text { comfort can be measured } \\
\text { with instruments applicable } \\
\text { in pediatrics; guidelines for } \\
\text { practice are provided; }\end{array}$ & $\begin{array}{l}\text { The comfort theory can be } \\
\text { easily applied to the context } \\
\text { of pediatric nursing care; }\end{array}$ \\
\hline
\end{tabular}


Chart 3

\begin{tabular}{|c|c|c|c|c|c|}
\hline Title & $\begin{array}{c}\text { Year } \\
\text { Country }\end{array}$ & Outline & $\begin{array}{l}\text { Theoretical } \\
\text { Conception } \\
\text { Identified }\end{array}$ & Results & Main conclusions \\
\hline $\begin{array}{l}\text { Nursing Care } \\
\text { for the Families } \\
\text { of Hospitalized } \\
\text { Children and } \\
\text { Adolescents }^{(35)}\end{array}$ & $\begin{array}{l}2019 \\
\text { Brazil }\end{array}$ & $\begin{array}{l}\text { Objective: to describe strategies } \\
\text { adopted by nurses to care for } \\
\text { families of hospitalized children and } \\
\text { adolescents; } \\
\text { Population: nurses working in } \\
\text { paediatrics; sample: } 12 \text { nurses; } \\
\text { Methodology: semi-structured } \\
\text { interviews analyzed using a computer } \\
\text { program; }\end{array}$ & $\begin{array}{l}\text { Systems theory, } \\
\text { by Neuman; }\end{array}$ & $\begin{array}{l}\text { The following strategies } \\
\text { were identified: bonding, } \\
\text { communication, health } \\
\text { education; looking for } \\
\text { support in the multi- } \\
\text { professional team; listening; } \\
\text { quiet professional posture; }\end{array}$ & $\begin{array}{l}\text { The use of systems theory } \\
\text { frames the care provided } \\
\text { to families of hospitalized } \\
\text { children and adolescents; is a } \\
\text { facilitator, as it aims to reduce } \\
\text { system responses (family) } \\
\text { to environmental stressors } \\
\text { (hospitalization); }\end{array}$ \\
\hline $\begin{array}{l}\text { Nursing care } \\
\text { through the } \\
\text { perception of } \\
\text { hospitalized } \\
\text { children }^{(36)}\end{array}$ & $\begin{array}{l}2016 \\
\text { Brazil }\end{array}$ & $\begin{array}{l}\text { Objective: to develop a proposal for } \\
\text { a nursing process to implement the } \\
\text { systematization of nursing care in a } \\
\text { pediatric hospital; }\end{array}$ & $\begin{array}{l}\text { Theory of basic } \\
\text { human needs, } \\
\text { by Wanda } \\
\text { Horta; }\end{array}$ & $\begin{array}{l}\text { Two categories were } \\
\text { identified: nurses' } \\
\text { knowledge about the } \\
\text { systematization of nursing } \\
\text { care; the strengths and } \\
\text { weaknesses that nurses face } \\
\text { in the construction of the } \\
\text { nursing process; }\end{array}$ & $\begin{array}{l}\text { Theoretical knowledge, } \\
\text { associated with practical care } \\
\text { experiences, is fundamental } \\
\text { for the construction of } \\
\text { all phases of the nursing } \\
\text { process; }\end{array}$ \\
\hline $\begin{array}{l}\text { Partnership } \\
\text { opportunities in } \\
\text { caring for children } \\
\text { with special health } \\
\text { needs: the parents' }^{\prime} \text { perspective }^{(37)}\end{array}$ & $\begin{array}{c}2015 \\
\text { Portugal }\end{array}$ & $\begin{array}{l}\text { Objective: to understand how the care } \\
\text { partnership is experienced by parents } \\
\text { of children with special health needs; } \\
\text { Population: parents of hospitalized } \\
\text { children with special health needs; } \\
\text { sample: } 10 \text { parents; } \\
\text { Methodology: qualitative, descriptive } \\
\text { and exploratory study with narrative } \\
\text { method; ethno-biographical } \\
\text { orientation interview; }\end{array}$ & $\begin{array}{c}\text { Care } \\
\text { partnership } \\
\text { model; }\end{array}$ & $\begin{array}{l}\text { There were two partnership } \\
\text { opportunities: parent } \\
\text { training; and decision- } \\
\text { making in partnership; }\end{array}$ & $\begin{array}{l}\text { The partnership in caring } \\
\text { for children with special } \\
\text { health needs, from the } \\
\text { parents' perspective, is } \\
\text { understood as a relational } \\
\text { and development process, } \\
\text { dynamic, unique and } \\
\text { continuous established } \\
\text { between parents and } \\
\text { nurses, centered on training } \\
\text { opportunities for child care } \\
\text { and taking shared decision: }\end{array}$ \\
\hline $\begin{array}{l}\text { Parental exercise } \\
\text { during the child's } \\
\text { hospitalization }^{(38)}\end{array}$ & $\begin{array}{c}2012 \\
\text { Portugal }\end{array}$ & $\begin{array}{l}\text { Objective: to identify the therapeutic } \\
\text { intentions of nurses when they } \\
\text { promote the partnership of care } \\
\text { with parents during the child's } \\
\text { hospitalization; } \\
\text { Population: parents of hospitalized } \\
\text { children and nurses working in } \\
\text { pediatric services; sample: } 103 \text { parents } \\
\text { (phase } 1 \text { - questionnaires); } 5 \text { nurses } \\
\text { and } 22 \text { mothers (phase } 1 \text { - interviews) } \\
444 \text { fathers (phase 1); } \\
\text { Methodology: action-research study } \\
\text { with application of observation, } \\
\text { interviews and questionnaires; }\end{array}$ & $\begin{array}{c}\text { Care } \\
\text { partnership } \\
\text { model; }\end{array}$ & $\begin{array}{l}\text { The child's hospitalization } \\
\text { is an event in personal life } \\
\text { related to the parental role. } \\
\text { The experiences can be } \\
\text { seen in two perspectives: } \\
\text { hospitalization generates } \\
\text { an interruption in the usual } \\
\text { pattern of performance } \\
\text { of the maternal role; the } \\
\text { self-awareness about the } \\
\text { changes and differences } \\
\text { that need to be introduced } \\
\text { in the exercise of the } \\
\text { maternal role usually } \\
\text { performed until now, due to } \\
\text { the child's health status; }\end{array}$ & $\begin{array}{l}\text { Seven objectives were } \\
\text { identified: promoting } \\
\text { parental participation in } \\
\text { developmental care (usual } \\
\text { care); promoting parenting } \\
\text { skills to provide complex } \\
\text { care; promoting parental } \\
\text { participation in complex } \\
\text { care when parental skills } \\
\text { were assessed as effective; } \\
\text { improvement in the } \\
\text { performance of parents to } \\
\text { perform complex care when } \\
\text { a potential for enhancing } \\
\text { the skills of parents to } \\
\text { perform complex care was } \\
\text { identified; reduction of the } \\
\text { stress level associated with } \\
\text { the parental role in parents } \\
\text { of children with permanent } \\
\text { special needs, facilitating, } \\
\text { during hospitalization, } \\
\text { rest in the role; preparing } \\
\text { parents to provide complex } \\
\text { care; preparing parents } \\
\text { to promote the child's } \\
\text { autonomy; }\end{array}$ \\
\hline $\begin{array}{l}\text { Communication } \\
\text { between children } \\
\text { and health } \\
\text { professionals in } \\
\text { a child hospital } \\
\text { setting: a Child } \\
\text { Transitional } \\
\text { Communication } \\
\text { Model }^{(18)}\end{array}$ & $\begin{array}{l}2011 \\
\text { Ireland }\end{array}$ & $\begin{array}{l}\text { Objective: to identify the nature of } \\
\text { communication between children and } \\
\text { health professionals in the hospital } \\
\text { context; } \\
\text { Population: children hospitalized in } \\
\text { inpatient services; sample: } 49 \text { children } \\
\text { from } 6 \text { to } 16 \text { years old; } \\
\text { Methodology: ethnographic study } \\
\text { with semi-participant observation, } \\
\text { unstructured interviews, participatory } \\
\text { activities and documented evidence; }\end{array}$ & $\begin{array}{c}\text { Child } \\
\text { transitional } \\
\text { communication } \\
\text { model; }\end{array}$ & $\begin{array}{l}\text { Health professionals } \\
\text { position children either as } \\
\text { passive spectators or as } \\
\text { active participants in the } \\
\text { communication process; }\end{array}$ & $\begin{array}{l}\text { Children prefer to swing } \\
\text { between passive viewers } \\
\text { and active participants in } \\
\text { the communication process } \\
\text { depending on their needs } \\
\text { over time; }\end{array}$ \\
\hline
\end{tabular}




\begin{tabular}{|c|c|c|c|c|c|}
\hline Title & $\begin{array}{c}\text { Year } \\
\text { Country }\end{array}$ & Outline & $\begin{array}{l}\text { Theoretical } \\
\text { Conception } \\
\text { Identified }\end{array}$ & Results & Main conclusions \\
\hline $\begin{array}{l}\text { Nurses } \\
\text { perceptions } \\
\text { of barriers to } \\
\text { implementing } \\
\text { family-centered } \\
\text { care in a pediatric } \\
\text { setting: A } \\
\text { qualitative study }{ }^{(39)}\end{array}$ & $\begin{array}{l}2017 \\
\text { Turkey }\end{array}$ & $\begin{array}{l}\text { Objective: to explore nurses' view of } \\
\text { their practice with FCCs; } \\
\text { Population: nurses at a pediatric } \\
\text { hospital; sample: } 18 \text { nurses; } \\
\text { Methodology: qualitative study with } \\
\text { application of interviews; }\end{array}$ & $\mathrm{FCCs}$; & $\begin{array}{l}\text { Two themes emerged: } \\
\text { nurses'opinions and views } \\
\text { on parental participation; }\end{array}$ & $\begin{array}{l}\text { Nurses have a positive view } \\
\text { of FCCs and recognize the } \\
\text { need for the family to remain } \\
\text { present in the child's life; } \\
\text { the cultural characteristics } \\
\text { of families are an obstacle; } \\
\text { the application of the } \\
\text { model implies not only their } \\
\text { conceptual knowledge, } \\
\text { but also an understanding } \\
\text { of the rights, roles and } \\
\text { responsibilities of parents; }\end{array}$ \\
\hline $\begin{array}{l}\text { Evaluating how } \\
\text { paediatric nurses } \\
\text { perceive the } \\
\text { family-centred } \\
\text { model of care and } \\
\text { its use in daily } \\
\text { practice }{ }^{(40)}\end{array}$ & $\begin{array}{l}2018 \\
\text { Greece }\end{array}$ & $\begin{array}{l}\text { Objective: to understand nurses' } \\
\text { perceptions about FCCs and how they } \\
\text { apply it in daily practice; } \\
\text { Population: nurses at a paediatric } \\
\text { hospital; sample: } 183 \text { nurses; } \\
\text { Methodology: quantitative study using } \\
\text { questionnaires; }\end{array}$ & FCCs; & $\begin{array}{l}\text { FCCs were considered } \\
\text { important for the sample; } \\
\text { their implementation was } \\
\text { correlated with: experience, } \\
\text { age, marital status and } \\
\text { having children; }\end{array}$ & $\begin{array}{l}\text { The importance of FCCs is } \\
\text { well established, however } \\
\text { nurses do not understand } \\
\text { that it is essential to apply } \\
\text { them in all aspects of daily } \\
\text { care practice; }\end{array}$ \\
\hline $\begin{array}{l}\text { Family-centred } \\
\text { care for children in } \\
\text { hospital|(41) }^{\text {(n) }}\end{array}$ & $\begin{array}{l}2007 \\
\text { England }\end{array}$ & $\begin{array}{l}\text { Objective: to investigate the effects of } \\
\text { FCC models on hospitalized children } \\
\text { when compared to other models of } \\
\text { care focused on the child, family and } \\
\text { results of the use of health services; } \\
\text { Population and sample: not applicable; } \\
\text { Methodology: systematic literature } \\
\text { review; }\end{array}$ & $\mathrm{FCCs}$; & $\begin{array}{l}\text { No studies were found that } \\
\text { met the inclusion criteria; }\end{array}$ & $\begin{array}{l}\text { The lack of quantitative } \\
\text { studies on the use of this } \\
\text { model is highlighted. }\end{array}$ \\
\hline
\end{tabular}

Note: TT - Therapeutic Toy; FCCs - Family Centered Care.

Regardless of the term used, theoretical conceptions of nursing are taught in educational institutions, integrated in the practice of care and used to guide research, thus promoting the advancement of nursing as a discipline.

Within the scope of nursing care in child and paediatric health, the context in which this review focuses, references to different theoretical concepts were found, and the family-centered care philosophy emerges in 8 of the 21 articles selected for this review, that is, it is the most mentioned theoretical conception. In the last decades, FCCs have been followed, in the area of paediatrics, by several disciplines in which nursing is included ${ }^{(42)}$ as the dominant theoretical framework assumed by many health organizations, professionals and institutions $s^{(43)}$. It is a perspective of care that sees the child integrated into the family, which is why hospitalization should not interrupt this connection. They are defined as an approach in the scope of care where there is a partnership between the family and health professionals $s^{(44)}$. They adopt nine central principles: recognition of the family as a constant in the child's life; facilitating collaboration between parents and health professionals at all levels of health care; respect for the racial, ethnic, cultural and socio-economic diversity of families; recognition of the strengths and individuality of each family, respecting the different coping methods; continuous sharing with the family of complete and unbiased information; encouragement and facilitation of family and network support; responding to the developmental needs of the child and family as an integral part of health care practices; adoption of policies and practices that give families emotional and financial support; and flexible health care planning, culturally competent and responsive to family needs $\mathrm{s}^{(41)}$.
FCCs are seen as a challenging care approach for nurses, but with benefits described, namely: increased satisfaction with health care and improvement in the comfort and welcome of the child and family ${ }^{(35)}$. It is understood as an important instrument, however, it is not clearly defined, being addressed in different countries with different designations ${ }^{(32)}$. There seem to be gaps in its applicability, especially in the effective action of nurses, as highlighted by Mendes \& Martins in a study developed in the Portuguese context ${ }^{(29) ;}$ in the absence of support, reported by Khajeh et al. in a study carried out in $\operatorname{Iran}^{(32)}$; and guidance to parents, pointed out by Coyne in a study that took place in Ireland ${ }^{(10)}$. The works found emphasize that the applicability of FCCs implies conceptual knowledge on the part of nurses ${ }^{(39)}$ and correlates with factors such as professional experience, age, having/not having children and marital status ${ }^{(40)}$. Therefore, the difficulty of its operationalization in practice is recognized, being identified as an abstract concept ${ }^{(42)}$. It is concluded that, although it is referred to as the most adequate theoretical conception for the context of the child's hospitalization, there is still little research that proves its greater effectiveness in comparison to other theoretical perspectives.

It should be noted that the basic principles of FCCs support other theoretical concepts, such as the Duffy \& Hoskins qualitycare mode ${ }^{(20)}$, and also integrate the theory of human care ${ }^{(17)}$. They appear as particularly appropriate to the context of the child's hospitalization ${ }^{(31)}$, because they are based on central concepts such as relationships and caring ${ }^{(45)}$.

Two of the theoretical concepts identified were developed specifically for the paediatric population and focus on aspects that 
are characteristic of paediatric care, namely the use of therapeutic toys ${ }^{(19)}$ and the nature of communication between professionals and children ${ }^{(18)}$. There is also the adaptation to the child population of theoretical concepts commonly used in the adult population, such as the quality-care model ${ }^{(20)}$; the synergy model ${ }^{(21)}$; the comfort theory ${ }^{(22)}$; the theory of human care ${ }^{(17)}$; the theory of basic human needs ${ }^{(15)}$ and the model of Neuman systems ${ }^{(23)}$. These mirror the breadth of these concepts and their suitability for different care contexts in which child health is included.

The care partnership, presented by Anne Casey ${ }^{(16)}$, is also identified in this literature review ${ }^{(37-38)}$. It is based on the principle that parents are capable and want to take care of their children in a disease situation, placing the emphasis on the care provided by the family, and this implies that this should be the focus of nursing care ${ }^{(46)}$. In this sense, he stresses that the role of nurses is one of support and support, replacing the care usually provided by parents only when they are not able to do $\mathrm{it}^{(16)}$. In this way, the care partnership is aligned with the FCCs and, in fact, Arabiat et al. ${ }^{(47)}$ refer that they derive from such a theoretical perspective, having evolved from their key ideas.

Miranda et al. ${ }^{(30)}$ conducted an analysis of the evolution of nursing theorization in the care of hospitalized children in Brazil, identifying three types: centered on pathology; child-centered; and child-centered and family. Recent literature brings arguments about the need for more integrative models, which consider not only the family, but also the child as the target of care and an effective member of the health team ${ }^{(48-49)}$. Child-centered care has been referred to as a perspective that considers the realization of children's rights, advocating the need to collect information directly from them, involving them in all stages of the care process ${ }^{(50)}$.

\section{Study limitations}

A limitation of this work refers to the evaluation of the quality of the articles. Since it is optional according to the PRISMA-SCR methodology, it was not carried out on this route by the authors decision. However, it could have provided a different look at the discussion of the results.

\section{Contributions to the Nursing Area}

The contribution to the identification of theoretical references in use for the provision of nursing care is highlighted, in line with the most recent scientific research. The literature review process allowed the verification of the variability of theoretical conceptions in use and the lack of studies that show their reasoned use.

\section{FINAL CONSIDERATIONS}

The scoping review allowed the identification of several theoretical concepts, used in the context of nursing care in children's hospitalization. The lack of consensus in the adopted terminology is highlighted, as well as the scarcity of scientific evidence to support the use of the theoretical concepts found. Although FCCs are assumed to be the dominant and most accepted theoretical conception, the applicability of other theoretical currents is verified in specific contexts that meet the needs of the child and his family during hospitalization.

Finally, the need for more integrative theoretical conceptions that put care in perspective - considering all the actors involved - and focus them both on the child and the family.

\section{REFERENCES}

1. Chinn PL, Kramer MK. Knowledge development in nursing : theory and process. 10th ed. Missouri: Elsevier Inc.; 2018.314 p.

2. Saleh US. Theory guided practice in nursing. J Nurs Res Pr [Internet]. 2018[cited 2020 Aug 10];2(1):18. Available from: https://www.pulsus. com/scholarly-articles/theory-guided-practice-in-nursing.pdf

3. Jairath NN, Peden-McAlpine CJ, Sullivan MC, Vessey JA, Henly SJ. Theory and Theorizing in Nursing Science. Nurs Res [Internet]. 2018 [cited 2020 Aug 10];67(2):188-95. Available from: http://journals.Iww.com/00006199-201803000-00015

4. Masters K. Nursing Theories: a framework for professional practice. Burlington: Jones \& Bartlett Learning; 2015. 406 p.

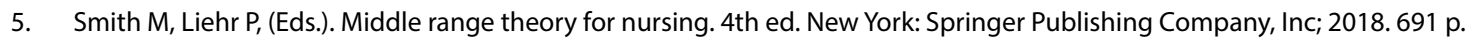

6. Tomey AM, Alligood MR. Teóricas de Enfermagem e a sua obra. Loures: Lusociência; 2004.

7. Leandro TA, Nunes MM, Teixeira IX, Lopes MVO, Araújo TL, Lima FET, et al. Development of middle-range theories in nursing. Rev Bras Enferm. 2020;73(1):1-8. https://doi.org/10.1590/0034-7167-2017-0893

8. LoBiondo-Wood G, Haber J. Nursing research : methods and critical appraisal for evidence-based practice. New York: Mosby; 2018.531 p.

9. Grove SK, Gray JR. Understanding nursing research: building an evidence based practice. 7th ed. Missouri: Elsevier; 2019.528 p.

10. Coyne I. Families and health-care professionals' perspectives and expectations of family-centred care: hidden expectations and unclear roles. Health Expect [Internet]. 2015 [cited 2019 Jul 2];18(5):796-808. Available from: https://onlinelibrary.wiley.com/doi/pdf/10.1111/ hex.12104

11. Macedo IF, Souza TV, Oliveira ICS, Cibreiros SA, Morais RCM, Vieira RFC. Nursing team's conceptions about the families of hospitalized children. Rev Bras Enferm. 2017;70(5):904-11. https://doi.org/10.1590/0034-7167-2016-0233

12. Tricco AC, Lillie E, Zarin W, O'Brien KK, Colquhoun H, Levac D, et al. PRISMA Extension for Scoping Reviews (PRISMA-ScR): checklist and explanation. Ann Intern Med [Internet]. 2018[cited 2019 Jul 2];169(7):467. Available from: http://annals.org/article.aspx?doi=10.7326/ M18-0850 
13. Levac D, Colquhoun H, O'Brien KK. Scoping studies: advancing the methodology. Implement Sci [Internet]. 2010 [cited 2019 Jul 1];5(1):69. Available from: https://pubmed.ncbi.nlm.nih.gov/20854677/

14. Peters M, Godfrey CM, Mcinerney P, Baldini Soares C, Khalil H, Parker D. Guidance for the Conduct of JBI Scoping Reviews. In: Aromataris E, Munn Z, (Eds.). Joana Briggs Institute Reviewer's Manual. Joanna Briggs Institute; 2017. p. 141-6. https://doi.org/10.1097/ XEB. 0000000000000050

15. Horta WA. Enfermagem: teoria, conceitos, princípios e processo. Rev Esc Enferm USP. 1974;8(1):7-17. https://doi. org/10.1590/0080-6234197400800100007

16. Casey A. Development and use of the partnership model of nursing care. In: Glasper EA, Tucker A, (Eds.). Advances in Child Health Nursing. Oxford: Scutari Press; 1993. p. 183-93.

17. Watson J. Assessing and measuring caring in nursing and health sciences. 2nd ed. New York: Springer Publishing Company, Inc; 2009.336 p.

18. Lambert V, Glacken M, McCarron M. Communication between children and health professionals in a child hospital setting: a child transitional communication model. J Adv Nurs [Internet]. 2011 [cited 2019 Jul 2];67(3):569-82. Available from: http://doi.wiley. com/10.1111/j.1365-2648.2010.05511.x

19. Caleffi CCF, Rocha PK, Anders JC, Souza AIJ, Burciaga VB, Serapião LS. Contribution of structured therapeutic play in a nursing care model for hospitalised children. Rev Gaúcha Enferm [Internet]. 2016[cited 2019 Jul 2];37(2). Available from: https://www.scielo.br/pdf/rgenf/v37n2/ en_0102-6933-rgenf-1983-144720160258131.pdf

20. Duffy JR, Hoskins LM. The Quality-Caring Model@. Adv Nurs Sci [Internet]. 2003[cited 2019 Jul 2];26(1):77-88. Available from: http://content. wkhealth.com/linkback/openurl?sid=WKPTLP:landingpage\&an=00012272-200301000-00010

21. Curley MA. Patient-nurse synergy: optimizing patients' outcomes. Am J Crit Care [Internet]. 1998 [cited 2020 Mar 4];7(1):64-72. Available from: http://www.ncbi.nlm.nih.gov/pubmed/9429685

22. Kolcaba K. Comfort Theory and Practice: a vision for holistic health care and research. New York: Springer Publishing Company; 2003.264 p.

23. Fawcett J, Neuman B. The Neuman Systems Model. Upper Saddle River, NJ: Pearson Education (US); 2011.448 p.

24. Santos MR, Bousso RS, Vendramim P, Baliza MF, Misko MD, Silva L. The practice of nurses caring for families of pediatric inpatients in light of Jean Watson. Rev Esc Enferm USP [Internet]. 2014 [cited 2019 Jun 8];48(spe):80-6. Available from: https://pubmed.ncbi.nlm.nih. gov/25517839/

25. Mullen JEA, Asher LM. Implementation of a nursing professional practice model of care in a pediatric hospital. Pediatr Nurs [Internet]. 2007[cited 2019 Jul 2];33(6):499-504. Available from: https://pubmed.ncbi.nlm.nih.gov/18196713/

26. Dantas AMN, Silva KL, Nóbrega MML. Validation of nursing diagnoses, interventions and outcomes in a pediatric clinic. Rev Bras Enferm. 2018;71(1):80-8. https://doi.org/10.1590/0034-7167-2016-0647

27. Marques DKA, Silva KL, Nóbrega MML. Escolares hospitalizados: proposta de um instrumento para coleta de dados à luz da teoria de Horta. Rev Gaúcha Enferm. 2016;37(spe). https://doi.org/10.1590/1983-1447.2016.esp.2016-0038

28. Santos MR, Silva L, Misko MD, Poles K, Bousso RS. Desvelando o cuidado humanizado: percepções de enfermeiros em oncologia pediátrica. Texto Contexto Enferm. 2013;22(3):646-53. https://doi.org/10.1590/S0104-07072013000300010

29. Mendes M, Martins M. Parceria nos cuidados de enfermagem em pediatria: do discurso à ação dos enfermeiros. Rev Enferm Ref. 2012;lllSérie(no6):113-21. https://doi.org/10.12707/RIII1144

30. Miranda AR, Oliveira AR, Toia LM, Stucchi HKO. A evolução dos modelos de assistência de enfermagem à criança hospitalizada nos últimos trinta anos: do modelo centrado na doença ao modelo centrado na criança e família. Rev Fac Ciênc Méd Sorocaba[Internet]. 2015[cited 2019 Jul 2];17(5):5-9. Available from: https://revistas.pucsp.br/index.php/RFCMS/article/view/12890

31. Edmundson E. The Quality caring nursing model: a journey to selection and implementation. J Pediatr Nurs. 2012;27(4):411-5. https:// doi. org/10.1016/j.pedn.2011.09.007

32. Khajeh M, Dehghan Nayeri N, Bahramnezhad F, Sadat Hoseini AS. Family centered care of hospitalized children: a hybrid concept analysis in Iran. Health Promot Perspect [Internet]. 2017[cited 2019 Jul 2];7(4):210-5. Available from: http://hpp.tbzmed.ac.ir/Abstract/ HPP_19199_20170606124421

33. Watts R, Zhou H, Shields L, Taylor M, Munns A, Ngune I. Family-centered care for hospitalized children aged 0-12 years: a systematic review of qualitative studies. JBI Database Syst Rev Implement Reports [Internet]. 2014 [cited 2019 Jul 2];12(7):204-83. Available from: https:// insights.ovid.com/crossref?an=01938924-201412070-00018

34. Kolcaba K, DiMarco MA. Comfort Theory and its application to pediatric nursing. Pediatr Nurs [Internet]. 2015 [cited 2019 Jul 4];31(3):18794. Available from: http://www.ncbi.nlm.nih.gov/pubmed/16060582

35. Ferreira L, Oliveira J, Gonçalves R, Elias T, Medeiros S, Mororó D. Nursing care for the families of hospitalized children and adolescents. Rev Enferm UFPE. 2019;13(1):23-31. https://doi.org/10.5205/1981-8963-v13i1a237672p23-31-2019

36. Santos P, Silva L, Depianti J, Cursino E, Ribeiro C. Nursing care through the perception of hospitalized children. Rev Bras Enferm. 2016;69(4):646-53. Available from: https://doi.org/10.1590/0034-7167.2016690405i

37. Alves J. Oportunidades de parceria no cuidar de crianças com necessidades especiais de saúde: a perspetiva dos pais [Internet]. Universidade Católica Portuguesa; 2015 [cited 2019 Jul 2]. Available from: http://hdl.handle.net/10400.14/18056 
38. Sousa PCMM. O exercício parental durante a hospitalização do filho [Internet]. Universidade Católica Portuguesa; 2012 [cited 2019 Jul 2]. Available from: http://hdl.handle.net/10400.14/13972

39. Boztepe H, Yıldız G. Nurses perceptions of barriers to implementing family-centered care in a pediatric setting: a qualitative study. J Spec Pediatr Nurs [Internet]. 2017 [cited 2019 Jul 2];22(2):e12175. Available from: http://doi.wiley.com/10.1111/jspn.12175

40. Matziou V, Manesi V, Vlachioti E, Perdikaris P, Matziou T, Chliara Jl, et al. Evaluating how paediatric nurses perceive the family-centred model of care and its use in daily practice. Br J Nurs [Internet]. 2018 [cited 2019 Jul 2];27(14):810-6. Available from: http://www.magonlinelibrary. com/doi/10.12968/bjon.2018.27.14.810

41. Shields L, Pratt J, Davis LM, Hunter J. Family-centred care for children in hospital. Cochrane Database Syst Rev. 2007;(1):CD004811. https:// doi.org/10.1002/14651858.CD004811.pub2

42. Smith W. Concept analysis of family-centered care of hospitalized pediatric patients. J Pediatr Nurs. 2018;42:57-64. https://doi.org/10.1016/j. pedn.2018.06.014

43. Shevell M, Oskoui M, Wood E, Kirton A, Van Rensburg E, Buckley D, et al. Family-centred health care for children with cerebral palsy. Dev Med Child Neurol [Internet]. 2019 [cited 2019 Jul 2];61(1):62-8. Available from: https://onlinelibrary.wiley.com/doi/abs/10.1111/dmcn.14053

44. Kuo DZ, Houtrow AJ, Arango P, Kuhlthau KA, Simmons JM, Neff JM. Family-Centered Care: Current Applications and Future Directions in Pediatric Health Care. Matern Child Health J [Internet]. 2012[cited 2017 Mar 16];16(2):297-305. Available from: http://link.springer. com/10.1007/s10995-011-0751-7

45. Azevêdo AVS, Lançoni Jr AC, Crepaldi MA. Interação equipe de enfermagem, família, e criança hospitalizada: revisão integrativa. Ciênc Saúde Coletiva [Internet]. 2017[cited 2019 May 27];22(11):3653-66. Available from: http://www.scielo.br/pdf/csc/v22n11/en_1413-8123csc-22-11-3653.pdf

46. Coyne I, Cowley S. Challenging the philosophy of partnership with parents: a grounded theory study. Int J Nurs Stud [Internet]. 2007 [cited 2019 Jul 8];44(6):893-904. Available from: https://linkinghub.elsevier.com/retrieve/pii/S0020748906000769

47. Arabiat D, Whitehead L, Foster M, Shields L, Harris L. Parents' experiences of Family Centred Care practices. J Pediatr Nurs [Internet]. 2018;42:39-44. Available from: https://linkinghub.elsevier.com/retrieve/pii/S0882596318300575

48. Coleman LN, Wathen $\mathrm{K}$, Waldron M, Mason JJ, Houston S, Wang Y, et al. The child's voice in satisfaction with hospital care. J Pediatr Nurs [Internet]. 2020;50:113-20. Available from: https://doi.org/10.1016/j.pedn.2019.11.007

49. Hargreaves DS, Sizmur S, Pitchforth J, Tallett A, Toomey SL, Hopwood B, et al. Children and young people's versus parents' responses in an English national inpatient survey. Arch Dis Child [Internet]. 2018 [cited 2019 Jul 2];103(5):486-91. Available from: http://www.ncbi.nlm.nih. gov/pubmed/29434020

50. Ford K, Dickinson A, Water T, Campbell S, Bray L, Carter B. Child centred care: challenging assumptions and repositioning children and young people. J Pediatr Nurs [Internet]. 2018 [cited 2019 Jul 2];43:e39-43. Available from: https://linkinghub.elsevier.com/retrieve/pii/S0882596318301660 